\title{
The Chang 7 member of the upper Triassic in the southwest Ordos Basin: Carbon isotope studay of dispersed organic matter and its paleoclimate significance
}

\author{
Yang Minghui $^{1 *}$, Liu Chiyang ${ }^{2}$, Tang $X$ uan $^{3}$ and Zheng Xiaofeng ${ }^{1}$ \\ ${ }^{1}$ Basin \& Reservoir Research Center; Key Laboratory of Hydrocarbon Accumulation, Ministry of Education, China \\ University of Petroleum, Beijing 102249, China \\ ${ }^{2}$ Department of Geology, Northwest University, Xi'an 710069, Shaanxi, China \\ ${ }^{3}$ Department of Energy Geology, China University of Geosciences, Beijing 100083, China
}

\begin{abstract}
The carbon isotope $\delta{ }^{13} \mathrm{C}$ value of dispersed organic matter in the Upper Triassic sediments in the Ordos basin is $(-24.5$ to -26.6$) \times 10^{-3}$ with the carbon being derived from C3-like pleustons. The paleoclimate of the Late Triassic, especially during the deposition of the Chang 7 member, was characterized by a hot and humid climate. It underwent four small climate cycles from humid and warm to humid and hot.
\end{abstract}

Key words: Paleoclimate; stable carbon isotope; dispersed organic material; Yanchang Formation; Ordos basin

Ratios of stable isotopes of organic carbon in lacustrine sediments can provide information about climatic change. This indirect relation has led to a useful application of the isotope approach to studying the paleoclimate both in China and overseas. One method is to study $\delta^{13} \mathrm{C}$ and $\delta^{16} \mathrm{O}$ values of carbonate minerals or microfossils in sediments (Kelts, 1992; Zhang et al, 1994); the other is to investigate $\delta^{13} \mathrm{C}$ values of organic matter in lacustrine sediments (Zhang et al, 1998; Horiuchi and Hoshino, 2000; Wang et al, 2002; Mingram and Brüchmann, 2004; Ma et al, 2004; Liu et al, 2005), in order to understand the changes of lake environment in which organic matter has been created and preserved (Sanger, 1998; Shen et al, 1998).

This study is a preliminary attempt to investigate paleoclimate change based on studies of stable carbon isotopeas of dispersed organic matter in the Chang 7 Oil Layer Member (OLM) of the Yanchang Formation in the Ordos basin.

\section{Sampling and analytic method}

The Upper Triassic Yanchang Formation in the Ordos basin represents an integral evolution of a nonmarine basin, from earlier basin subsidence (Chang 8) to widespread basin expansion (Chang 7), then to basin contraction (Chang 6) and expansion again (Chang 4+5), inversion and extinction (Chang 1). The deep and shallow lacustrine deposits of the Chang 7 OLM were laid down as a lake expanding system

*Corresponding author. email: yang.mh@263.net

Received October 12, 2006 tract, in which the Zhangjiatan shale was deposited during the maximum flooding period. The sampled well Zhen 33 is located in the southwestern Ordos basin (Fig.1) with samples being taken from well depths of 2213-2220.4 $\mathrm{m}$ in which the Chang 7 OLM of the Yanchang Formation is composed of lacustrine mudstone and silty mudstone. Samples were evenly taken at a sampling interval of $20 \mathrm{~cm}$.

Dispersed organic matter was prepared with the Separation Method of Kerogen in Sedimentary Rock, following the national standard GB/T19144-2003. The testing procedure for obtaining the $\delta^{13} \mathrm{C}$ value is as follows: (1) At a low temperature $\left(<60^{\circ} \mathrm{C}\right)$, dispersed organic matter was obtained by drying and was pulverized to a size of 100 mesh. 1-5 g samples were used depending on carbon content; (2) Samples were put into clean beakers, and then left for 24 hours in dilute hydrochloric acid to remove carbonate minerals. Afterwards, the sample was flushed with distilled water till neutral and dried at low temperature $\left(<75^{\circ} \mathrm{C}\right)$. The sample was tested with an analyzer CS-344 model; (3) The treated sample was put into a quartz boat. Then the boat was placed in high temperature vacuum oven fitted with copper oxide and silver for $15 \mathrm{~min}$. The sample was sufficiently burnt at the constant temperature of $900^{\circ} \mathrm{C}$ with pure oxygen; (4) The generated $\mathrm{CO}_{2}$ was transferred and pure $\mathrm{CO}_{2}$ gas was obtained with liquid nitrogen and cold liquid; (5) The $\delta{ }^{13} \mathrm{C}$ value of $\mathrm{CO}_{2}$ gas was determined by a mass spectrometer of MAT-251 model.

$\delta^{13} \mathrm{C}$ value can be calculated as follows: $\delta^{13} \mathrm{C}=\left[\left(\delta^{13} \mathrm{C} / \delta^{12} \mathrm{C}\right)_{\text {sample }}-\left(\delta^{13} \mathrm{C} / \delta^{12} \mathrm{C}\right)_{\text {standard }}\right]$ $/\left(\delta^{13} \mathrm{C} / \delta^{12} \mathrm{C}\right)_{\text {standard }}$ 
The accuracy of instrumental analyses is $\pm 0.02 \%$. The analytical results are reported with the reference to the international standard of PDB (Fig.2).

\section{Results and environment interpretation}

The organic matter in lacustrine sediments was mainly derived from terrigenous detrital materials and aquatic plants, but the organic carbon isotope of lacustrine sediments was derived from the fractionation of organic carbon isotope of land and aquatic plants. Currently, there are two factors affecting the fractionating process of carbon isotope of land plants. One is the manner and the other is the extent of photosynthesis. Nearly $90 \%$ of the initial product from photosynthesis is phosphoric acid and glyceric acid with three carbon molecules, the $\mathrm{C}_{3}$ cycle. The characteristics of the process present a long cycle and a large fractionating level, and the $\delta{ }^{13} \mathrm{C}$ values fall in the range of $-23 \%$ to $-38 \%$. The other photosynthesis path is called as $\mathrm{C}_{4}$ cycle. The initial product is dihydroxy acid with four carbon molecules. Although its assimilatory rate of $\mathrm{CO}_{2}$ is two times that of $\mathrm{C}_{3}$ cycle, the degree of fractionation distillation is smaller and $\delta^{13} \mathrm{C}$ values are in the range of $-12 \%$ o to $-14 \%$. The type of plant photosynthesis determines the isotopic fractionation(Smith and Epstein, 1971; Bown, 1988) while different sorts of plants are closely connected with their growing environment. Thus, the measured $\delta^{1 /} \mathrm{C}$ values of

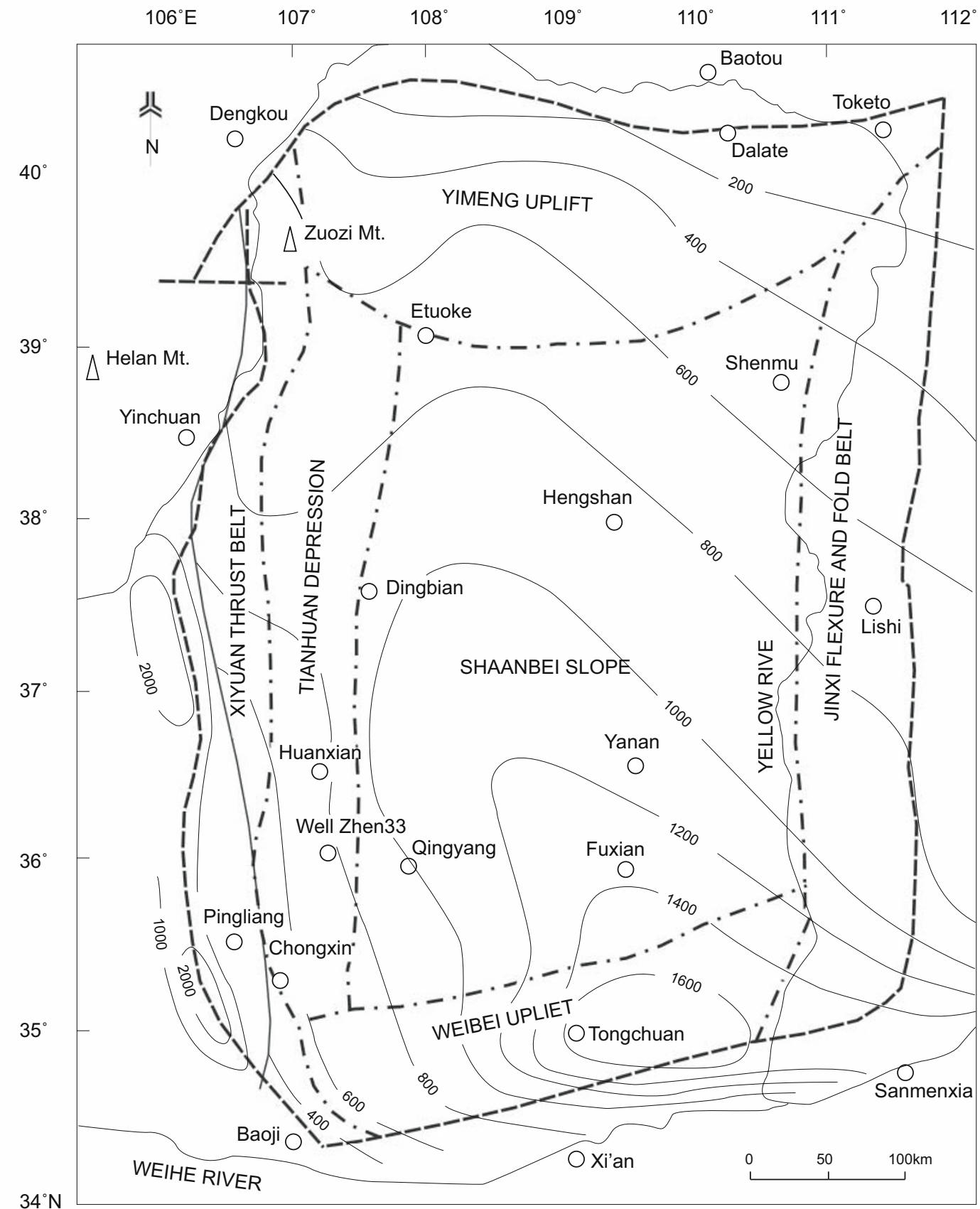

Fig. 1 Structural subdivision map of the Ordos basin showing the location of the Well Zhen 33 The contours illustrate the isopach of the Yanchang Formation 


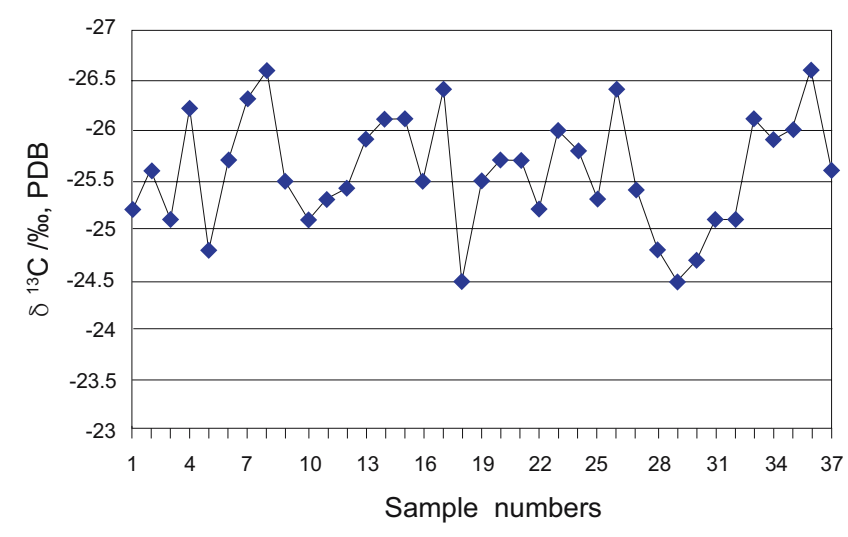

Fig. 2 Sequence change of $\delta^{13} \mathrm{C}$ values of dispersed organic matter in the Upper Triassic in the southwestern Ordos basin

organic matter in sediments can be used to define the pattern of vegetation from which organic carbon was derived and the pattern in turn can be utilized to study the type of paleoclimate environment (Nakai, 1972; Stuiver, 1975; Wu and Lu, 1992; Cormie and Schwarcz, 1994). The aquatic plants can be divided into pleustons and submerged plants. The pleustons include emerging plants, floating-leaved plants and phytoplanktons. The $\delta^{13} \mathrm{C}$ values of the pleustons are close to those of the $\mathrm{C}_{3}$ plants. For example, the $\delta^{13} \mathrm{C}$ values of emerging plants are about $-24 \%$ to $-30 \%$.

Microscopic examination of dispersed organic matter in the Chang 7 OLM indicates that the types of organic matter in the sediments vary slightly with the depth and the sorts of plants are more or less homogeneous in terms of stratigraphic distribution. The organic matter consists of dominant amorphous maceral with no fluorescence or weak to moderate fluorescence and subordinate inertinite and vitrinite. The dispersed organic matter in the Chang 7 OLM has $\delta^{13} \mathrm{C}$ values of $-24.5 \%$ o to $-26.6 \%$. They were mainly derived from $\mathrm{C}^{3}$ plants and possibly pleustons.

Evaporation on plant leaves is intensive in high temperatures. In order to decrease evaporation of water, plants adjust themselves in the following ways: to shut down some of the micropores of leaves, reduce passage of micropores, decrease $\mathrm{CO}_{2}$ concentration inside leaves, and finally make $\delta^{13} \mathrm{C}$ values of plant cellulose increase. On the contrary, $\delta^{13} \mathrm{C}$ values of plant cellulose decrease in low temperatures. The relationship between the $\quad \delta^{13} \mathrm{C}$ values of organic matter in lacustrine sediments and climate is as follows: the $\mathrm{C}_{4}$ plants (producing higher $\delta^{13} \mathrm{C}$ values) are favored in a warm and dry climate. The higher the temperature, the longer the sunlight, the more vigorous the growth. The $\quad \delta^{13} \mathrm{C}$ value is $-10 \%$ to $-21 \%$ with an average of $-14 \%$. In contrast, $\mathrm{C}_{3}$ plants tend to grow at a lower temperature and weak sunlight environment. Their $\delta^{13} \mathrm{C}$ values are lower, and generally fall in the range of $-21 \%$ to $-33 \%$ with an average of $-27 \%$. The $\mathrm{C} 3$ plants (having lower $\delta^{13} \mathrm{C}$ values) are widely distributed. Their $\delta^{3} \mathrm{C}$ values are controlled by temperature. Higher temperature can significantly enhance photosynthesis, and the $\delta^{13} \mathrm{C}$ value of $\mathrm{C}_{3}$ plants become more negative (Bown, 1988) due to the dynamic effects of isotope. The less negative the $\delta^{13} \mathrm{C}$ value of $\mathrm{C}_{3}$ plants, the lower the growing environment temperature of plants. Except for temperature constraint, $\mathrm{C}_{3}$ plants are also controlled by moisture. Based on such reasoning, the depositional environment during the deposition of the sampled Chang 7 is deduced to be wet and hot, and it underwent four microclimate cycles from warm and wet to wet and hot with sample no. 27, 19 and 9 marking the cycle boundaries).

\section{Discussion and conclusions}

Pre-existing studies show that the plants with different modes of photosynthesis (e.g. $\mathrm{C}_{3}, \mathrm{C}_{4}$ and CAM) have different $\delta^{13} \mathrm{C}$ values. The change of the $\delta^{13} \mathrm{C}$ values of sedimentary organic matter are related to the $\delta^{13} \mathrm{C}$ values of plant sources. When the plants absorb $\mathrm{CO}_{2}$ for photosynthesis, it will lead to carbon isotope fractionation. During this process, many environmental factors (such as pressure of $\mathrm{CO}_{2}$ in atmosphere, $\mathrm{O}_{2}$ partial pressure, temperature, moisture, light and salinity etc.) affect carbon isotope fractionation and the isotopic composition of plants (Fig.3).

The relationship between temperature and the sedimentary organic matter $\delta^{3} \mathrm{C}$ value is more complex, and no consensus has been reached for this relationship. They may be negatively or positively correlated in different areas of plateau or plain and so on (Wu et al, 1996). The components of organic matter $\delta^{13} \mathrm{C}$ in lacustrine sediments are enriched in the heavy carbon isotope as air temperature increases in the plain area. This is because (1) $\mathrm{C}_{4}$ plants reduce rapidly as latitude increases; (2) With increasing latitude, the temperature becomes lower so that the concentration of the $\mathrm{CO}_{2}$ dissolved in water increases. The process for pleustons to synthesize organic matter has an inverse relationship with the supplied volume of $\mathrm{CO}_{2}$. As a result, the more $\mathrm{CO}_{2}$ that is provided, the more negative the $\quad \delta^{13} \mathrm{C}$ values in synthesized organic matter. Moisture is also one of the important factors affecting the change of $\delta^{13} \mathrm{C}$ in plants. As water molecule forces leaves of plants to shutdown vesicles and reduce leaf micropore connectivity, the rate for plants to absorb and assimilate $\mathrm{CO}_{2}$ decreases. The $\mathrm{CO}_{2}$ differential pressure declines inside and outside of the leaf cells, which causes the $\delta^{13} \mathrm{C}$ values of plants fixed by photosynthesis to become more negative. This shows that

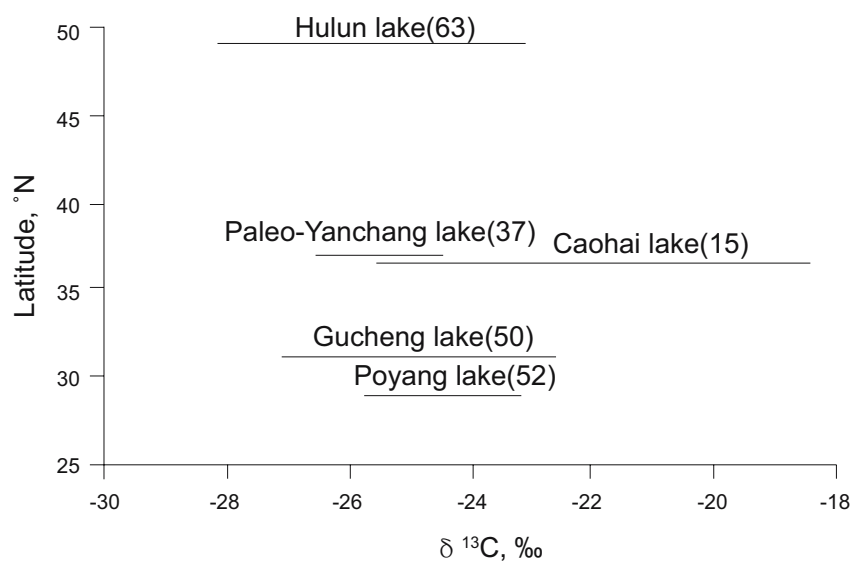

Fig. 3 The cross plot between lacustrine sedimentary organic matter $\delta^{13} \mathrm{C}$ values and latitude (modified from Wu et al, 1996) 
low precipitation will also favor more negative $\delta^{13} \mathrm{C}$ values. Thus, organic matter $\delta^{13} \mathrm{C}$ values of Chang 7 OLM tend to become less negative with an increasing temperature and an increasing humidity .

\section{References}

Bown R. Isotopes in the Earth Sciences. London, Elsevier Applied Science. 1988: 456-457

Cormie A B and Schwarcz H P. Stable isotopes of nitrogen and cabon of North American white-tailed deer and implications for paleodietary and other food web studies. Palaeogeogr. Palaeclimatol. Palaeoecol.. 1994. 107: 227-241

Horiuchi K and Hoshino K. Palaeoenvironmental history of Lake Baikal during the last 23000 years. Palaeogeogr. Palaeoclimatol. Palaeoecol.. 2000. 157(1-2): 95-108

Kelts K. Lacustrine bog deposition: information storage of past changes. Quaternary Research Work. 1992. (2): 138-143 (in Chinese)

Liu Q, Gu Z Y, Liu J L, et al. Bulk organic carbon isotopic record of Huguangyan maar lake, southeastern China and its paleoclimatic and paleoenvironmental significance since $62 \mathrm{kabp}$. Marine Geology \& Quaternary Geology. 2005. 25(2): 115-126 (in Chinese)

Ma Z X, Huang J H, Wei Y, et al. Organic carbon isotope records of the Poyang Lake sediments and their implications for the paleoclimate during the last $8 \mathrm{ka}$. Geochimica. 2004. 33(3): 279-285 (in Chinese)

Mingram J and Brüchmann C. Maar-and crater lakes of the Long Gang Volcanic Field (N. E. China) - Overview, laminated sediments, and vegetation history of the last 900 years. Quaternary International. 2004. 123-125: 135-147

Nakai N. Carbon isotopic variation and the paleoclimate of sediments from Lake Biwa. Proc. Jap. Acad.. 1972. 48: 516-521

Sanger J E. Fossil pigments in paleoecology and plaeolimnology. Palaeogeogr. Palaeclimatol. Palaeoecol.. 1988. 62: 279-282

Shen J, Wang S M and Zhang G. Dissolvable organic composition and its Paleoclimatic environmental significance in sediments of the Gucheng lake. Journal Of Lake Science. 1998. 10(4): 63-70 (in Chinese)

Smith B N and Epstein S. Two categories of $13 \mathrm{C} / 12 \mathrm{C}$ ratios for higher plants. Plant Physiology. 1971. 47: 380- 384

Stuiver M. Climate versus change in $13 \mathrm{C}$ content of the organic component of lake sediments during the Late Quaternary. Quaternary Research. 1975. 5: 251-262

Wang R L, Scarpitta S C, Zhang S C, et al. Later Pleistocene / Holocene climate conditions of Qinghai-Xizang Plateau (Tibet) based on carbon and oxygen stable isotopes of Zabuye lake sediments. Earth Planet Lett.. 2002. 203: 461-477

Wu J L, Wang S M, Shen J. Information of climate and environment deduced from the organic matter $\quad \delta{ }^{13} \mathrm{C}$ of lacustrine sediments. Journal of Lake Science. 1996. 8(2): 113-118 (in Chinese)

Wu N Q, Lu H Y. Paleoclimate significance of study on C3 and C4 plants and silicate body. Quaternary Research. 1992. (2): 241-249 (in Chinese)

Zhang P X, Zhang B Z, Qian G M, et al. The study of paleoclimatic parameter of Qinghai lake since Holocene. Quaternary Sciences. 1994. (3): 225-236 (in Chinese)

Zhang Z K, Wu R J, Wang S M, et al. Climate evolution recorded by organic carbon stable isotope ratios in Erhai lake in the past $8 \mathrm{ka}$ years. Marine Geology \& Quaternary Geology. 1998. 18(3): 23-29 (in Chinese)

(Edited by Yang Lei) 